\title{
AKUNTANSI SYARIAH SEBAGAI SISTEM INFORMASI
}

\author{
Rahmat Ilyas \\ IAIN Syaikh Abdurrahman Siddik Bangka Belitung, Indonesia \\ mtd_82@yahoo.com \\ https://doi.org/10.46367/jas.v4i2.254
}

Received: Nov 07, 2020 Revised: Nov 26, 2020 Accepted: Dec 05, 2020 Published: Dec 16, 2020

\begin{abstract}
Accounting as an information system identifies collecting and communicating economic information about a business entity to various people. Accounting is at the forefront and plays an important role in running our economy and social system. Decisions taken by individuals, governments, other business entities are determined in terms of their use of the resources owned by a nation. One of the most important aspects of an entity is the financial aspect and financial reporting records that have a major impact on the sustainability of the entity. This research is entirely library research. The purpose of this study is to determine how Islamic accounting is an information system. The analytical method used is the content analysis method. The results of this study indicate that Islamic accounting is an effort to deconstruct modern accounting in a humanist and value-laden form. Islamic accounting information systems highlight Islamic values both in the object of accounting and information systems, Islamic accounting information systems have a great responsibility in moral matters.
\end{abstract}

Keywords: Sharia Accounting, Information, Information System.

\begin{abstract}
ABSTRAK
Akuntansi sebagai suatu sistem informasi, mengidentifikasi mengumpulkan dan mengkomunikasikan informasi ekonomi mengenai suatu badan usaha kepada beragam orang. Akuntansi menjadi yang terdepan dan berperan penting dalam menjalankan ekonomi dan sistem sosial kita. Keputusan-keputusan yang diambil oleh individu-individu, pemerintah, badan usaha lain ditentukan dalam penggunanya pada sumber daya yang dimiliki suatu bangsa. Salah satu aspek yang paling penting dalam entitas adalah aspek keuangan dan pencatatan pelaporan keuangan yang memiliki dampak besar terhadap keberlangsungan entitas tersebut. Penelitian ini sepenuhnya merupakan riset perpustakaan. Tujuan dari penelitian adalah untuk mengetahui terkait bagaimana akuntansi syariah sebagai sistem informasi. Metode analisis yang digunakan yaitu metode content analysis. Hasil penelitian ini menunjukkan bahwa akuntansi syariah merupakan salah satu upaya mendekonstruksi akuntansi modern dalam bentuk yang humanis dan sarat akan nilai. Sistem informasi akuntansi syariah menonjolkan nilai-nilai Islam baik itu dalam objek akuntansinya maupun sistem informasinya, sistem informasi akuntansi syariah mempunyai tanggungjawab yang besar dalam masalah moral.
\end{abstract}

Kata Kunci: Akuntansi Syariah, Informasi, Sistem Informasi. 


\section{PENDAHULUAN}

Praktik sistem keuangan syariah telah dilakukan sejak zaman kejayaan Islam. Namun seiring melemahnya sistem khalifah pada akhir abad ke-19, dinasti Ottoman memperkenalkan sistem perbankan barat pada dunia Islam. Tetapi pada akhir tahun 1970-an mulailah berdiri bank yang mengadopsi sistem syariah dan berkembang pesat. Pada saat ini banyak negara yang telah melakukan kegiatan perdagangan dan bisnis menggunakan sistem syariah (Ilyas 2017, 123).

Lahirnya sistem syariah dilatarbelakangi oleh bekembangnya masyarakat muslim di Indonesia yang diiringi dengan kesadaran terhadap ketidakadilan skema perbankan konvensional. Secara konseptual, praktik akuntansi syariah hadir sebagai solusi atas permasalahan transaksi konvensional yang tidak sesuai dengan nilai-nilai Islami. Aspek-aspek akuntansi konvensional tidak dapat diterapkan pada lembaga yang menerapkan prinsip-prinsip Islam, baik dari implikasi akuntansi maupun akibat ekonomi.

Teori akuntansi syariah merupakan bagian dari praktik akuntansi syariah yang diperlukan sebagai landasan dalam pengembangan praktik akuntansi syariah. Pemahaman yang benar tentang teori akuntansi syariah akan mendorong perkembangan akuntansi menuju praktik akuntansi yang sesuai dengan prinsipprinsip syariah. Menurut Apriyanti (2017) bahwa praktik akuntansi syariah hadir sebagai jawaban atas permasalahan transaksi konvensional yang tidak sesuai dengan nilai-nilai syariah. Teori akuntansi syariah diperlukan untuk menjelaskan berbagai asumsi dasar yang mendasari praktik akuntansi syariah di Indonesia dan menjelaskan praktik akuntansi yang sudah berjalan dan landasan dalam pengembangan akuntansi syariah pada masa akan datang (Apriyanti 2017, 138).

Beberapa tahun belakangan ini terjadi peningkatan kajian terhadap bidang akuntansi menuju perspektif Islam. Salah satu aspek yang mendorongnya adalah dengan munculnya sistem perbankan syariah khususnya di Indonesia. Di sisi lain, tidak semua aspek akuntansi konvensional dapat diterapkan pada lembaga yang menggunakan prinsip-prinsip syariah baik dari implikasi akuntansi maupun akibat ekonomi. Oleh karena itu perlu adanya penerapan sistem informasi terkait dengan standar akuntansi yang sesuai dengan lembaga keuangan syariah. Beberapa isu lain yang mendorong munculnya akuntansi syariah adalah harmonisasi standar akuntansi internasional di negara-negara Islam.

Akuntansi menjadi yang terdepan dan berperan penting dalam menjalankan ekonomi dan sistem sosial kita. Keputusan-keputusan yang diambil oleh individu, pemerintah atau badan usaha lainnya ditentukan oleh penggunanya pada sumber daya yang dimiliki suatu bangsa. Salah satu aspek yang paling penting dalam entitas adalah aspek keuangan dan pencatatan pelaporan keuangan yang memiliki dampak besar terhadap keberlangsungan entitas tersebut (Suherman 2019, 65).

Sebagai suatu sistem informasi, akuntansi diperlukan oleh berbagai pihak, baik dari kalangan internal maupun dari luar organisasi yang menyelenggarakan akuntansi tersebut. Organisasi menggantungkan diri pada sistem informasi untuk mempertahankan kemampuan dalam berkompetisi. Informasi pada dasarnya adalah sumber daya seperti halnya pabrik dan peralatan. Produktivitas, sebagai suatu hal yang penting agar tetap kompetitif, dapat ditingkatkan melalui sistem informasi yang lebih baik. 
Akuntansi dalam konteks sistem informasi akuntansi memiliki peranan penting untuk efisiensi maupun efektifitas perusahaan dan dapat meningkatkan pengambilan keputusan sehingga kinerja perusahaan dapat ditingkatkan (Cahyadi et al. 2020, 2). Saat ini hampir semua perusahaan, apapun bidangnya, pasti memerlukan sistem informasi akuntansi, tidak terkecuali perusahaan asuransi. Hasil penelitian Afrizon (2018) yang dikutip oleh Cahyadi et al. (2020, 2) menyebutkan bahwa belum berkualitasnya informasi akuntansi disebabkan Sistem Informasi Akuntansi yang belum memadai.

Berdasarkan penjelasan diatas serta masih terbatasnya pembahasan khusus mengenai akuntansi syariah sebagai suatu sistem informasi, maka peneliti bertujuan untuk menelaah terkait pentingnya akuntansi syariah sebagai sistem informasi kepada para pengguna atau pemangku kebijakan dalam satu lembaga atau perusahaan.

\section{TELAAH LITERATUR}

Akuntansi sering dihadapkan pada berbagai masalah yang menyangkut transaksi yang memerlukan interpretasi atau analisis khusus seperti analisis eonomi, sosial, hukum, statistik dan politik (Ikhsan et al. 2015, 55). Wacana akuntansi tidak lahir dalam ruang yang kosong, tetapi hadir dalam proses interaksi sosial yang begitu kompleks dan dalam dimensi ruang waktu yang sangat dinamis. Kondisi objektif, seperti norma agama, kontribusi umat Islam pada masa lalu, sistem ekonomi kapitalis yang berlaku saat ini, dan perkembangan pemikiran, sangat berpengaruh dalam proses kelahiran paradigma akuntansi syariah. Akuntansi merupakan hal yang sangat penting dalam dunia bisnis, hal ini dititik beratkan setiap pengambilan sebuah keputusan dalam bisnis didasarkan informasi yang diperoleh dari akuntansi. Keberadaan informasi menjadi begitu penting dalam setiap tahapan pengambilan keputusan, baik dari mulai proses pengidentifikasian persoalan, mapun memonitoring setiap pelaksanaan keputusan yang diterapkan (Ikhsan et al. 2015).

Perkembangan pesat terjadi dalam kegiatan usaha dan lembaga keuangan (bank, asuransi, pasar modal, dana pensiun dan lain sebagainya) yang berbasis syariah. Dalam tiga dekade terakhir lembaga keuangan telah meingkatkan volume dan nilai transaksi berbasis syariah yang tentunya meningkatkan kebutuhan terhadap akuntansi syariah. Selanjutnya perkembangan pemikiran mengenai akuntansi syariah juga makin berkembang, hal ini ditandai dengan makin diterimanya prinsip-prinsip transaksi syariah di dunia internasional (Nurhayati and Wasilah 2019, 3).

Standar akuntansi sebagai acuan penyusunan laporan keuangan yang berlaku disuatu negara, akan berbeda dengan standar akuntansi di negara lain. Perbedaan ini dipengaruhi oleh kondisi lingkungan, hukum, sosial, politik dan ekonomi di tiap-tiap negara. Masalah keterbandingan (Comparability) laporan keuangan, tingkat keandalan (reliability) dan peluang ketidakpastian menjadi konsekuensi dari adanya perbedaan standar akuntansi ini (Cahyono 2011, 1884).

Akuntansi syariah merupakan salah satu upaya mendekonstruksi akuntansi modern dalam bentuk yang humanis dan sarat akan nilai. Tujuan didirikannya akuntansi syariah adalah terciptanya peradaban bisnis dengan wawasan humanis, emansipatoris, transcendental dan theologikal. Dengan demikian, melalui 
akuntansi syariah realitas sosial akan dikontstruk melalui muatan mulai dari tauhid dan ketundukan pada jaringan-jaringan kuasa ilahi yang semuanya dilakukan dengan perspektif khalifatullah fil ardh. Tujuan akuntansi syari'ah sangat luas, namun demikian penekanannya adalah pada upaya untuk merealisasikan tegaknya syari'ah dalam kegiatan ekonomi yang dijalankan oleh manusia. Pada tataran ideal tujuan akuntansi syari'ah adalah sesuai dengan peran manusia di muka bumi dan hakikat pemilik segalanya maka sudah semestinya yang menjadi tujuan ideal dari laporan keuangan adalah pertanggungjawaban muamalah kepada Tuhan Sang Pemilik Hakiki, Allah SWT. (Arwani 2016, 128).

Filosofi dari akuntansi adalah accounting follows the business. Dalam konteks ini, perkembangan akuntansi merupakan respon dan evaluasi terhadap perkembangan bisnis. Dalam konteks ini akuntansi berkembang sesuai dengan dan dipengaruhi oleh perkembangan lingkungan (bisnis) (Alim 2011, 154).

\section{METODE PENELITIAN}

Penelitian ini sepenuhnya adalah riset perpustakaan (library research), yaitu penelitian yang kajiannya dengan menelusuri dan menelaah literatur-literatur dan penelitian yang difokuskan pada bahan-bahan pustaka. Dalam hal ini obyek yang penulis maksudkan adalah buku-buku yang berkaitan dengan akuntansi syariah dan buku-buku yang mendukung lainnya.

Metode analisis data yang digunakan yaitu metode content analysis atau disebut dengan analisis isi, yaitu metode penelitian yang dimanfaatkan untuk menarik kesimpulan yang reflikatif dan shahih dari data atas dasar konteksnya. Untuk menggunakan metode content analysis diperlukan tiga syarat yang dipakai dalam analisis isi yaitu objektivitas, pendekatan sistematis dan generalisasi. Analisis harus berlandaskan aturan yang dirumuskan secara eksplisit. Untuk memenuhi syarat sistematis, untuk kategorisasi isi harus menggunakan kriteria tertentu. Hasil analisis haruslah menyajikan generalisasi, artinya temuannya haruslah mempunyai sumbangan teoritis, temuan yang hanya deskriftif rendah nilainya.

\section{PEMBAHASAN}

Akuntansi dalam bahasa arabnya adalah al-Muhasabah berasal dari kata masdar hassaba-yuhasbu yang artinya menghitung atau mengukur. Secara istilah, al-Muhasabah memiliki berbagai asal kata yaitu ahsaba yang berarti "menjaga" atau "mencoba mendapatkan" juga berasal dari kata Ihtiasaba yang berarti "mengharapkan pahala di akhirat dengan diterimanaya kitab seseorang dari Tuhan", juga berarti "menjadikan perhatian" atau "mempertanggungjawabkannya" (Mauludi 2014, 60).

Wacana akuntansi syariah muncul sebagai salah satu akibat bergulirnya wacana dan praktik perbankan syariah, yang berhulu dari semangat Islamisasi sistem ekonomi dikalangan umat Islam. Hal ini adalah sebuah konsekuensi logis dari tuntunan dari Islamisasi. Wacana akuntansi syariah ini muncul bersamaan dengan kehadiran lembaga perbankan syariah. Ini mudah dipahami, karena pada hakikatnya, mustahil memsahkan akuntansi dari kegiatan muamalah pada 
umumnya, bisnis komersial khususnya dan perbankan lebih khusus lagi (Suwikno 2010, vi).

Akuntansi merupakan kegiatan pencatatan keuangan yang berfungsi sebagai language of business. Proses akuntansi dimulai dari pengelompokan data transaksi hingga mengahasilkan laporan keuangan. Hasil dari proses akuntansi ini digunakan untuk laporan pertanggungjawaban kinerja perusahaan, sekaligus untuk data pengambilan keputusan dan perencanaan bisnis (Suwikno 2010, 11).

\section{Akuntansi Sebagai Sistem Informasi}

Akuntansi dapat dipandang sebagai suatu sistem yang mengolah masukan berupa data operasi dan data keuangan untuk menghasilkan keluaran berupa informasi akuntansi yang dibutuhkan oleh pemakai. Untuk itu seorang manajer akan membutuhkan akuntansi dalam menjalankan usahanya. Akuntansi manajemen dapat dilihat dari dua sisi yaitu, sebagai salah satu tipe akuntansi dan sebuah tipe informasi. Disini kita akan mebahas akuntansi manajemen sebagai tipe informasi.

Selain itu juga akuntansi merupakan suatu bahasa bisnis. Sebagai suatu bahasa, akuntansi merupakan alat untuk berpikir manajer dalam bisnis dan untuk mengkomunikasikan pikiran-pikiran bisnis manajer kepada bawahan dan atasannnya, kepada manajer lain, dan pihak luar. Oleh karena itu informasi merupakan sebuah informasi yang diperlukan dalam pengambilan keputusan.

Kegiatan akuntansi pada dasarnya merupakan kegiatan mencatat, menganalisis, menyajikan, dan menafsirkan data keuangan (lembaga, perusahaan dan lembaga lainnya). Aktivitas-aktivitas ini berhubungan dengan produksi, pertukaran barang dan jasa-jasa, dan pengelolaan dana-dana. Bagi perusahaan yang bertujuan memperoleh keuntungan akuntansi merupakan metode untuk menentukan apakah lembaga tersebut memperoleh keuntungan atau tidak, atau sebaliknya menderita kerugian, sebagai hasil dan transaksi-transaksi yang dilakukan. Akuntansi sebagai alat pembantu manajemen (tool of management), dapat memberikan informasi tentang kondisi keuangan dan hasil operasi perusahaan seperti tercermin pada laporan keuangan perusahaan yang bersangkutan (Suwikno 2010, 2).

Informasi merupakan suatu fakta, data, pengamatan, persepsi, atau sesuatu yang lain, yang menambah pengetahuan. Peran informasi ini digunakan untuk mengurangi ketidakpastian dan keragu-raguan dalam pengambilan keputusan. Pengambilan keputusan ini sangat mempengaruhi masa yang akan datang untuk itu sebelurn diputuskan akan terdapat beberapa alternatif tindakan yang mengandung kepastian.

Informasi itu sendiri dapat dibedakan menjadi dua yaitu informasi kuantitatif dan informasi non kuantitatif, sedangkan informasi kuantitatif dibedakan menjadi informasi akuntansi dan informasi non akuntansi, dan informasi akuntansi dibedakan menjadi informasi operasi, informasi akutansi keuangan, dan informasi akuntansi manajemen.

Manajemen memerlukan informasi, baik yang berupa informasi kuantitatif maupun nonkuantitatif sebagai dasar pengambilan keputusan. Paengambilan keputusan selalu berupa pemilihan altematif, dan setiap pemilihan alternatif selalu mengandung ketidakpastian. Informasi berperan sebagai pengurang ketidakpastian, sehingga manjemen mampu menjatuhkan pilihan. Informasi 
kuantitatif lebih berperan dalam mengurangi ketidakpastian bila dibandingkan dengan informasi non kuantitatif.

Akuntansi merupakan salah satu informasi yang diperlukan oleh manajemen. Untuk itu hendaknya manajer mengerti tentang akuttansi. Manajer yang tidak rnenguasai akutansi sebagai bahasa bisnis tidak akan dapat berfikir secara bisnis karena tidak merniliki alat berpikir untuk itu. Seorang manajer puncak yang tidak tahu mengenai peran akuntansi dalam rnempengaruhi perilaku para manajer yang ada dibawahnya dalam mencapai tujuan perusahaan.

lnformasi akuntansi sebagai bahasa bisnis dikelompokkan menjadi tiga golongan yaitu: (1) Informasi operasi, manajemen memerlukan berbagai informasi operasi seperti jumlah kilogram bahan baku yang dipakai dalam produksi, jumlah persediaan produk jadi yang ada digudang, jumlah produksi hari ini, jumlah jam kerja karyawan dalam satu minggu dan jumlah produk yang dijual hari ini. Informasi operasi ini akan mempengaruhi informasi akutansi keuangan dan informasi akuntansi manajemen. (2) Informasi akuntansi keuangan, diperlukan oleh manajemen maupun pihak luar perusahaan seperti pemegang saham, bankir dan kreditur yang lain, instansi pemerintahr dan pihak luar yang lain. Informasi akutansi keuangan ini diperlukan oleh pihak luar untuk pengambilan keputusan guna menentukan hubungan antara pihak luar tersebut dengan perusahaan. Informasi akuntansi keuangan ini disajikan dalam bentuk laporan keuangan. (3) Informasi akuntansi manajemen, diperlukan oleh manajemen untuk melaksanakan dua fungsi pokok manajemen yaitu perencanaan dan pengendalian aktivitas perusahaan. informasi akuntansi manajemen ini disajikan kepada manajemen perusahaan dalam berbagai laporan keuangan seperti anggaran, laporan penjualan, laporan biaya produksi dan lain-lain.

Tipe-tipe Informasi akuntansi manajemen terdiri dari: (a) Informasi akuntansi penuh, menyajikan informasi mengenai pendapatan total, biaya total dan atau aktiva total pada masa lalu maupun pada masa yang akan datang. lnformasi mengenai biaya penuh masa lalu (historical full cost digunakan untuk penyususnan laporan keuangan (umumnya berupa neraca dan laporan rugi laba). (b) Informasi akutansi diferensial, menyajikan informasi mengenai taksiran pendapatan, biaya dan atau aktiva yang berbeda jika suatu tindakan tertentu dipilih, dibandingkan dengan alternatif tindakan yang lain. Informasi akutansi diferensial berkaitan dengan masa yang akan datang. (c) lnformasi akuntansi pertanggtungjawaban, menyajikan informasi mengenai pendapatan biaya atau aktiva yang dikaitkan dengan suatu bagian atau unit di dalam perusahaan. Masingmasing bagian atau unit dipimpin oleh seoarang manajer yang bertangungjawab terhadap bagian yang bersangkutan. Bagian-bagian tersebut disebut sebagai pusatpusat pertangungjawaban. Informasi akuntansi pertanggungjawaban masa lalu bermanfaat untuk menganalisis prestasi dari masing-masing manajer pusat pertanggungiawaban, sedangkan informasi akuntansi pertangungjawaban yang menyangkut masa yang akan datang digunakan dalam kegiatan perencanaan, khususnya perencanaan lahunan yang dikenal dengan "anggaran (budget)".

\section{Fungsi dan Kegunaan Sistem Informasi Akuntansi}

Informasi memiliki nilai ekonomik pada saat ia mendukung keputusan alokasi sumber daya, sehingga dengan demikian mendukung sistem untuk mencapai tujuan. Sesungguhnya informasi dapat menjadi sumber daya informasi 
yang terpenting. Akuntansi sebagai suatu sistem informasi, mengidentifikasi mengumpulkan dan mengkomunikasikan informasi ekonomik mengenai suatu badan usaha kepada beragam orang. Informasi adalah data yang berguna yang diolah sehingga dapat dijadikan dasar untuk mengambil keputusan yang tepat. Sistem adalah kumpulan sumber daya yang berhubungan untuk mencapai tujuan tertentu. Sistem informasi akuntansi (SIA) adalah kumpulan sumberdaya, seperti manusia dan peralatan yang diatur untuk mengubah data menjadi informasi. Informasi ini dikomunikasikan kepada beragam pengambilan keputusan. SIA mewujudkan perubahan ini apakah secara manual atau terkomputerisasi. Setiap organisasi yang menggunakan komputer untuk memproses data transaksi memiliki fungsi sistem informasi. Fungsi sistem informasi bertanggung jawab untuk pengolahan data. Pengolahan data merupakan aplikasi sistem informasi akuntansi yang paling mendasar dalam setiap organisasi. Fungsi sistem informasi dalam organisasi telah berevolusi dari struktur organisasi sederhana yang meliputi beberapa orang saja sampai struktur yang kompleks yang meliputi banyak spesialis yang bermutu.

Kegunaan dari sistem informasi akuntansi antara lain yaitu: (a) Menyediakan informasi ekonomi suatu entitas (perusahaan) yang relevan digunakan dalam pengambilan keputusan ekonomi. (b) Sebagai media komunikasi manajemen selaku pengelola perusahaan dan stakeholder (pemilik perusahaan) mengenai kondisi keuangan, perubahan poisisi keuangan, dan arus kas (cash flow) perusahaan. (c) Memberikan gambaran mengenai kemampuan unit usaha dalam memberikan umpan balik ekonomi dari sumber daya yang digunakan. (d) Sebagai media pertanggungjawaban kepada stakeholders secara umum, mengenai segala sesuatu yang berhubungan dengan pengelolaan perusahaan. (e) Memberikan gambaran mengenai kemajuan perusahaan dari masa ke masa melalui kecendrungan (trend) perubahan perusahaan. (f) Menyediakan informasi yang berguna bagi investor/kreditor dan calon investor/kreditor dan penggunapengguna lainnya dalam membuat keputusan investasi, kredit, dan keputusankeputusan serupa lainnya secara rasional. (g) Menyediakan informasi yang membantu investor/kreditor dan calon investor/kreditor dan pengguna-pengguna lainnya dalam menilai jumlah, waktu dan ketidakpastian penerimaan kas dimasa depan yang berupa deviden, serta penerimaan-penerimaan kas lainnya yang diperoleh dari penjualan, pelunasan, dan jatuh temponya sekuritas dan pinjaman. (h) Menyediakan informasi yang secara jelas menggambarkan sumber daya ekonomi perusahaan, klaim atas sumber daya tersebut, dan pengaruh kejadian, transaksi, dan kedaan-keadaan yang mengubah sumber daya dan klaim atas sumber daya tersebut.

\section{Pengguna Sistem Informasi Akuntansi}

Sistem informasi akuntansi saat ini berkembang menjadi sistem informasi berbasis komputer yang dapat meningkatkan kepuasan pengguna karena kemudahan akses yang didapat dalam mengambil suatu keputusan. Sistem informasi akuntansi yang terkomputerisasi memungkinkan pemakai laporan keuangan dapat melihat laporan keuangan setiap saat dengan lebih cepat dan akurat. Penyajian informasi keuangan dan non-keuangan dapat dilakukan dengan lebih mudah dengan adanya dukungan paket program sistem informasi akuntansi 
yang dewasa ini semakin banyak variasinya dan dapat diperoleh dengan mudah di pasaran (Buana and Wirawati 2018, 684).

Pemanfaatan sistem informasi tersebut mencakup adanya pengolahan data, pengolahan informasi, sistem manajemen dan proses kerja secara elektronik dan pemanfaatan kemajuan teknologi informasi agar pelayanan publik dapat diakses secara mudah dan murah oleh masyarakat di seluruh wilayah (Lukiman and Lestarianto 2016, 50). Sebagai suatu sistem informasi, akuntansi diperlukan oleh berbagai pihak, baik dari kalangan intern maupun dari luar organisasi yang menyelenggarakan akuntansi tersebut. Secara garis besar pihak-pihak tersebut antara lain: (a) Manajer, manajer perusahaan rnenggunakan akuntansi untuk menyusun perencanaan perusahaannya, mengevaluasi kemajuan yang dicapai dalam usaha mencapai tujuan dan melakukan tildakan-tindakan koreksi yang diperlukan. (b) Investor, para investor harus melalukan analisis atas laporan keuangan perusahaan yang akan dipilih sebagai tempat penanaman modalnya. (c) Kreditur, calon kreditur harus menilai kemampuan keuangan calon pengambil kredit. Untuk itu kreditur selalu meminta laporan keuangan calon nasabah untuk dinilai. (d) lnstansi pemerintah, badan-badan pemerintah seperti badan pelayanan pajak atau badan pengembangan pasar modal (Bapepam) membutuhkan informasi keuangan dari perusahaan-perusahaan wajib pajak atau perusahaan yang menjual sahamnya melalui pasar rnodal. Informasi akuntansi merupakan sumber utama bagi badan pemerintah unfuk dapat menetapkan pajak perusahaan atau mengawasi perusahaan. (e) Organisasi nirlaba, organisasi keagamaan, yayasan atau lembaga pendidikan dan sejenisnya membutuhkan informasi akuntansi karena mereka juga harus mempunyai anggaran, membayar tenaga kerja, membayar listrik dan sewa, serta urusan-urusan keuangan lainnya. Semua hal tersebut bersangkutan dengan akutansi. (f) Pemakai lainnya, informasi akuntansi diperlukan juga oleh berbagai pihak-pihak lain untuk kepentingan-kepentingan tertentu, misalnya organisasi buruh, informasi akuntansi penting bagi para buruh dalam rangka mengajukan kenaikan gaji atau tunjangan-tunjangan lain dari perusahaan tempat mereka bekerja. Dengan pengguna informasi akuntansi yang beragam tersebut, maka akuntan harus dapat menyediakan informasi yang berkualitas yang mengandung unsur dapat dimengerti (understanability), relevan (relevance), dapat dipercaya (reliable), konsisten (consistency), dan memiliki daya banding (comparability) (Yeni et al. 2016, 683).

\section{Sistem Informasi Akuntansi Syariah}

Akuntansi syariah merupakan bagian dari kegiatan bisnis dengan konsep Islam yang mengandung muamalah dalam kajian Islam. Kegiatan muamalah merupakan kegiatan yang berhubungan degan mansia tetapi mempunyai nilai pertanggungjawaban dihadapan Allah SWT. Allah SWT. menempatkan permasalahan ini dalam surah Al-Baqarah ayat 282:

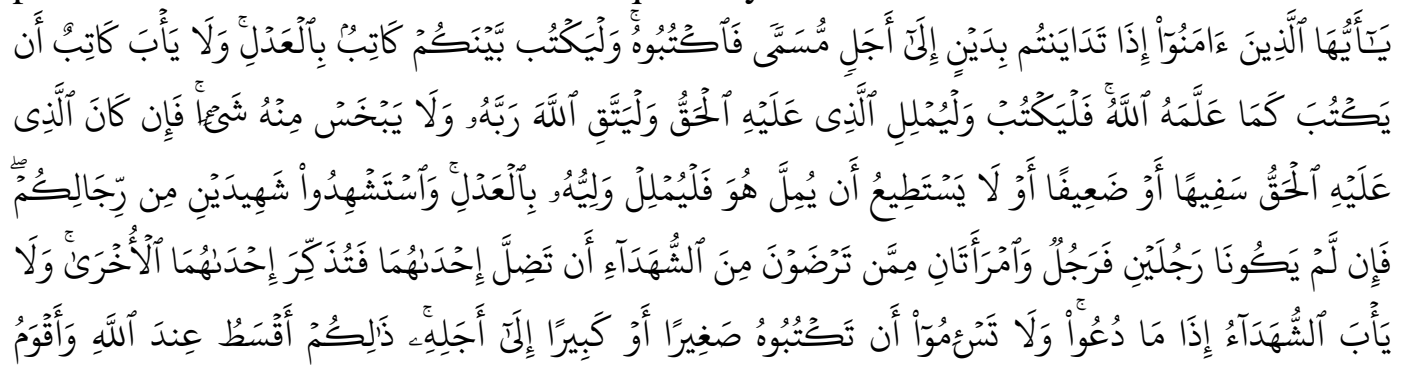




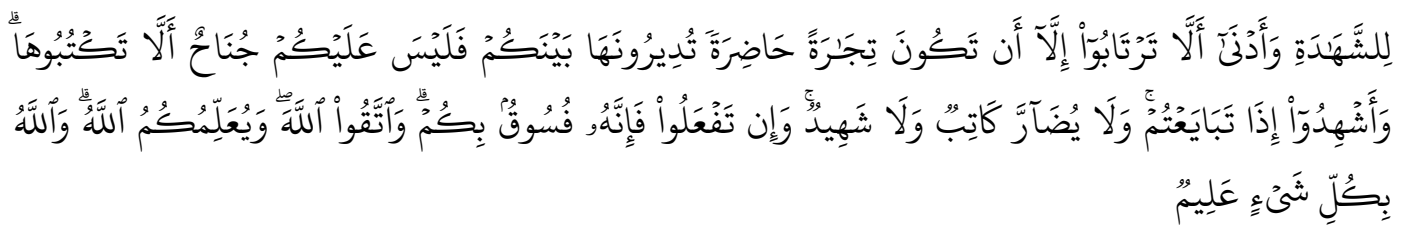

Artinya: "Hai orang-orang yang beriman, apabila kamu bermu'amalah tidak secara tunai untuk waktu yang ditentukan, hendaklah kamu menuliskannya. dan hendaklah seorang penulis di antara kamu menuliskannya dengan benar. dan janganlah penulis enggan menuliskannya sebagaimana Allah mengajarkannya, meka hendaklah ia menulis, dan hendaklah orang yang berhutang itu mengimlakkan (apa yang akan ditulis itu), dan hendaklah ia bertakwa kepada Allah Tuhannya, dan janganlah ia mengurangi sedikitpun daripada hutangnya. jika yang berhutang itu orang yang lemah akalnya atau lemah (keadaannya) atau Dia sendiri tidak mampu mengimlakkan, Maka hendaklah walinya mengimlakkan dengan jujur. dan persaksikanlah dengan dua orang saksi dari orang-orang lelaki (di antaramu). jika tak ada dua oang lelaki, Maka (boleh) seorang lelaki dan dua orang perempuan dari saksi-saksi yang kamu ridhai, supaya jika seorang lupa Maka yang seorang mengingatkannya. janganlah saksi-saksi itu enggan (memberi keterangan) apabila mereka dipanggil; dan janganlah kamu jemu menulis hutang itu, baik kecil maupun besar sampai batas waktu membayarnya. yang demikian itu, lebih adil di sisi Allah dan lebih menguatkan persaksian dan lebih dekat kepada tidak (menimbulkan) keraguanmu. (Tulislah mu'amalahmu itu), kecuali jika mu'amalah itu perdagangan tunai yang kamu jalankan di antara kamu, Maka tidak ada dosa bagi kamu, (jika) kamu tidak menulisnya. dan persaksikanlah apabila kamu berjual beli; dan janganlah penulis dan saksi saling sulit menyulitkan. jika kamu lakukan (yang demikian), Maka Sesungguhnya hal itu adalah suatu kefasikan pada dirimu. dan bertakwalah kepada Allah; Allah mengajarmu; dan Allah Maha mengetahui segala sesuatu.

Struktur akuntansi melukiskan unsur-unsur atau pihak-pihak dan saranasarana yang terlibat dalam dan terpengaruh oleh penentuan atau penyediaan informasi keuangan dan saling hubungan antara unsur-unsur tersebut. Pihak yang terlibat atau berkepentingan meliputi pelaku dan institusi misalnya penyusun standar, profesi, pemerintah, badan pembina pasar modal, perusahaan sebagai entitas, analis, manajer, akuntan publik, dan pemakai laporan. Sarana-sarana yang membentuk struktur akuntansi meliputi misalnya peraturan pemerintah, standar akuntansi, laporan keuangan, dan konvensi pelaporan (Ilyas 2016, 25).

Akuntansi dengan nilai-nilai Islam yang berlandaskan pada tanggung jawab, keadilan dan kebenaran yang sesuai dengan Al-Qur'an dan Al-Hadits merupakan suatu realita yang harus diupayakan. Kehidupan umat manusia yang berlandaskan agama (Islam) yang mengharapkan kesejahteraan dan kemakmuran serta kebahagian di dunia dan di akhirat yang didasarkan hubungan manusia dengan Tuhan (hablum minallah) dan hubungan sesama manusia (hablum minannas), maka memerlukan praktik yang ideal dan sesuai dengan hukumhukum syariah. Sehingga ada ketenangan hidup dan berkehidupan (bermuasyarat dan bermuamalah) yang sesuai dengan landasan hidupnya (Susilowati 2017, 296).

Akutansi konvensional yang sekarang berkembang adalah sebuah disiplin dan praktik yang dibentuk dan membentuk lingkungannya. Oleh karena itu, jika akuntansi dilahirkan dalam lingkungan kapitalis, maka informasi yang disampaikannya akan mengandung nilai-nilai kapitalis. Kemudian keputusan dan 
tindakan ekonomi yang diambil pengguna informasi tersebut juga mengandung nilai-nilai kapitalis. Singkatnya, informasi akuntansi yang kapitalistik akan membentuk jaringan kuasa yang kapitalistik juga. Jaringan inilah yang akhinya mengikat manusia dalam samsara kapitalisme.

Pada dasarnya informasi akuntansi syariah tidak jauh berbeda dengan informasi akuntansi konvensional. Namun dengan demikian tidaklah bisa dihukumi secara umum bahwa SIA yariah sama persis dengan SIA konvensional. Karena ada obyek dalam akuntansi syariah yang tidak terdapat dalam akuntansi konvensional. Dengan demikian informasi yang dihasilkan juga ada perbedaan, obyek-obyek dan pengguna SIA Syariah juga tidak sama dengan yang terdapat dalam SIA konvensional. Menurut standar akuntansi pemerintahan, kualitas informasi yang terkandung di dalam laporan keuangan meliputi dapat dipahami (understandability), relevansi (relevance), keterandalan (reliable), konsisten (consistency), dan dapat diperbandingkan (comparability) (Yeni et al. 2016, 683).

Pada dasarnya sistem informasi akuntansi syariah menonjolkan nilai-nilai Islam baik itu dalam objek akuntansinya maupun sistem informasinya, jadi sistem informasi akuntansi syariah mempunyai tanggungjawab yang besar dalam masalah moral. Tujuan penyusunan sistem informasi akuntansi syariah adalah sama dengan tujuan penyusunan sistem akuntansi antara lain: (a) Untuk menyediakan informasi bagi pengolah kegiatan usaha baru. (b) Untuk memperbaiki informasi yang dihasilkan oleh sistem yang sudah ada, baik mengenai mutu, ketepatan penyajian maupun struktur informasi. (c) Untuk memperbailai pengendalian akuntansi \& pengecekan internal (d) Untuk mengurangi biaya klerikal dalam penyelenggaraan catatan akuntansi (Tabe 2013).

Aspek informasi kualitatif bisa dikonfirmasi dari fungsi tujuan informasi akuntansinya yaitu sebagai doa dan dzikir. Tujuannya adalah untuk membangkitkan kesadaran berketuhanan pengguna dalam menjalankan aktifitas bisnis sesuai syariah dan ibadah serta pengingat akan kembalinya pada Tuhan (Alfia et al. 2018, 103). Untuk memenuhi tujuan ini, secara aksiologis menggunakan pendekatan teknologi neuro-linguistik, sehingga informasi akuntansi yang dihasilkan penuh doa dan dzikir (Triyuwono 2013). Teks (kualitatif) dalam hal ini memiliki nilai kekuatan spiritual, yang dapat memengaruhi pengguna untuk melakukan ibadah (bisnis) yang sesuai dengan ketentuan dan nilai-nilai Islam.

Dari beberapa uraian diatas dapat dipahami bahwa penerapan sistem informasi akuntansi syariah menonjolkan nilai-nilai Islam baik itu dalam objek akuntansinya maupun sistem informasinya senantiasa dianggap penting dalam pencatatan pembukuan sebuah perusahaan. Hal ini sejalan dengan pendapat Harahap yang dikutip oleh Siregar (2015) yang menyebutkan bahwa Islam menganggap bahwa transaksi ekonomi (muamalah) memiliki nilai urgensi yang sangat tinggi, sehingga adanya pencatatan dapat dijadikan sebagai alat bukti (hitam di atas putih), menggunakan saksi (untuk transaksi yang material) sangat diperlukan karena dikhawatirkan pihak-pihak tertentu mengingkari perjanjian yang telah dibuat.

Keberlangsungan sistem informasi akuntansi syariah diharapkan dapat memberikan dampak positif terhadap pengambilan keputusan sebuah dalam sebuah perusahaan. Hasil penelitian tentang pemanfaatan sistem informasi Akuntansi di Indonesia sudah dilakukan oleh Pramuka et al. (2010) yang 
menyimpulkan bahwa sistem informasi akuntansi mempunyai peranan yang penting dalam menjalankan fungsi manajemen dan menilai prestasi seseorang. Penelitian ini juga menunjukkan signifikansi pengaruh AIS terhadap kinerja manajer Bank Perkreditan Rakyat di Kabupaten Banyumas (Pramuka et al. 2015).

Hasil penelitian yang terkait dengan sistem informasi akuntansi menyatakan bahwa dukungan manajemen puncak (DMP) pada perusahaan asuransi syariah di Indonesia berpengaruh signifikan terhadap kualitas SIA. Namun demikian peranan DMP terhadap peningkatan kualitas SIA masih memerlukan dukungan pemilihan dan penempatan sumber daya insani yang memiliki kemampuan mengoperasikan sistem informasi dan dukungan pengembangan sumber daya manusia dan pelatihan. Secara teoritis, untuk meningkatkan kualitas SIA pada perusahaan asuransi syariah di Indonesia DMP mempunyai peranan sangat penting. Implikasinya manajemen harus terus memberikan dukungan positif terhadap kualitas SIA (Cahyadi 2020, 7). Selain itu juga penelitian lain menyebutkan bahwa salah satu cara mengukur kinerja keuangan lembaga keuangan mikro syariah adalah dengan melihat pada implementasi Sistem Informasi Akuntansi (SIA) dalam pencairan pinjaman dan pengembalian pinjaman (Kauffman and Riggins 2012).

\section{KESIMPULAN}

Akuntansi merupakan hal yang sangat penting dalam dunia bisnis, hal ini dititik beratkan setiap pengambilan sebuah keputusan dalam bisnis didasarkan informasi yang diperoleh dari akuntansi. Keberadaan informasi menjadi begitu penting dalam setiap tahapan pengambilan keputusan, baik dari mulai proses pengidentifikasian persoalan, mapun memonitoring setiap pelaksanaan keputusan yang diterapkan. Akuntansi syariah adalah merupakan salah satu upaya mendekonstruksi akuntansi modern dalam bentuk yang humanis dan sarat akan nilai. Tujuan didirikannya akuntansi syariah adalah terciptanya peradaban bisnis dengan wawasan humanis, emansipatoris, transcendental dan teologikal. Dengan demikian, melalui akuntansi syariah realitas sosial akan dikontstruk melalui muatan mulai dari tauhid dan ketundukan pada jaringan-jaringan kuasa ilahi yang semuanya dilakukan dengan perspektif khalifatullah fil ardh. Pada dasarnya sistem informasi akuntansi syariah menonjolkan nilai-nilai Islam baik itu dalam objek akuntansinya maupun sistem informasinya, jadi sistem informasi akuntansi syariah mempunyai tanggungjawab yang besar dalam masalah moral.

Hasil penelitian ini sangatlah terbatas pada sebatas telaah literatur yang berkaitan dengan sistem informasi akuntansi syariah, diharapkan kedepan agar para peneliti lain dapat melanjutkan riset yang terkait dengan akuntansi syariah, seperti implementasi akuntansi syariah dalam lembaga keuangan syariah di Indonesia dan topik-topik lain yang berhubungan dengan akuntansi syariah.

\section{DAFTAR PUSTAKA}

Alfia, Yulis diana, Iwan Triyuwono dan Aji Dedi Mulawarman. 2018 "Kritik Atas Tujuan Akuntansi Syariah: Perspektif Realitas Sadrian" Jurnal AKSI 
(Akuntansi dan Sistem Informasi) $3 \quad$ (2): 93-111. https://doi.org/10.32486/aksi.v2i2.266.

Alim, Mohammad Nizarul. 2011. "Akuntansi Syariah, Esensi, Konsep, Epistimologi dan Metodologi”. InFestasi: Jurnal Bisnis dan Akuntansi 7 (2): 154-161.

Apriyanti, Hani Werdi. 2017. “Akuntansi Syariah: Sebuah Tinjauan Antara Teori dan Praktik" Jurnal Akuntansi Indonesia 6 (2): 131-140. http://dx.doi.org/10.30659/jai.6.2.131-140.

Arwani, Agus. 2016. "Konstruksi Hukum Ekonomi Syariah Dalam Fiqh Anggaran Yang Bebasis Akuntansi Syariah". Al-Hakam: Jurnal Ilmu Syari'ah Dan Hukum 1 (2): 115-132. https://doi.org/10.22515/alahkam.v2i2.279.

Buana, Ida Bagus Gede Mawang Mangun, and Ni Gusti Putu Wirawati. 2018. "Pengaruh Kualitas Sistem Informasi, Kualitas Informasi, dan Perceived Usefulness Pada Kepuasan Pengguna Sistem Informasi Akuntansi”. EJurnal Akuntansi $\quad 22 \quad$ (1): 683-713. https://doi.org/10.24843/EJA.2018.v22.i01.p26.

Cahyono, Aris Tri. 2011. "Meta Teori Standar Akuntansi Keuangan Di IndonesiaMenuju Konvergensi SAK di Masa Globalisasi”. Jurnal Eksis 7 (2): 18841897.

Cahyadi, Wahyu, Murniati Mukhlisin, and Sigid Eko Pramono. 2020 "Pengaruh Dukungan Manajemen Puncak Terhadap Kualitas Sistem Informasi Akuntansi”. Jurnal Ilmiah MEA (Manajemen, Ekonomi, dan Akuntansi) 4 (1): $1-10$.

Ilyas, Rahmat. 2016 "Kerangka Dasar Penyusunan Dan Penyajian Laporan Keuangan Syariah". Asy-Syar'iyyah 1 (1): 19-41.

Ilyas, Rahmat. 2017 “Konsep Dasar Sistem Keuangan Syariah” Asy-Syar'iyyah 2 (1): 121-142.

Ikhsan, Arfan, Sukma Lesmana and Atma Hayat. 2015. Teori Akuntansi, Bandung: Citapustaka Media.

Lukiman, Renaldy, and JB Widodo Lestarianto. 2016 "Pengaruh Penerapan Sistem Informasi Akuntansi, Pemanfaatan Sistem Informasi, Efektivitas Penggunaan Sistem Informasi Akuntansi, Kepercayaan Atas Teknologi Sistem Informasi Akuntansi, Dan Teknologi Informasi Terhadap Kinerja Individu Karyawan" Ultima Accounting: Jurnal Ilmu Akuntansi 8 (2): 4665. https://doi.org/10.31937/akuntansi.v8i2.581.

Kauffman, Robert J., and Frederick J. Riggins. 2012 "Information and Communication Technology and the Sustainability of Microfinance" Electronic Commerce Research and Applications 11 (5): 450-468. https://doi.org/10.1016/j.elerap.2012.03.001.

Mauludi, Ali. 2014 "Akuntansi Syariah: Pendekatan Normatif, Historis dan Aplikatif" Jurnal Iqtishadia 1 (1): 59-75. http://dx.doi.org/10.19105/iqtishadia.v1i1.366.

Nurhayati, Sri and Wasilah. 2019. Akuntansi Syariah di Indonesia. Jakarta: Salemba Empat.

Pramuka, Bambang Agus, Siti Maghfiroh, and Sugiarto. 2015. "Sistem Informasi Akuntansi Berbasis Elektronik Pada Lembaga Keuangan Mikro Syariah". JP: Jurnal \& Proceding 5 (1): 1-14. 
Siregar, Budi Gautama. 2015 "Implementasi Akuntansi Dalam Kehidupan Menurut Perspektif Islam". Junal Al-Masharif 3 (1): 1-16.

Suherman, Lukas Pamungkas. 2019. "Analisis Pentingnya Akuntansi Pesantren: Studi pada Pondok Pesantren Al-Matuq Sukabumi”. Jurnal Akuntansi Terapan Indonesia 2 (2): 65-70. https://doi.org/10.18196/jati.020220.

Susilowati, Lantip. 2017 "Tanggung Jawab, Keadilan dan Kebenaran Akuntansi Syariah" An-Nisbah: Jurnal Ekonomi Syariah 3 (2): 295-320. https://doi.org/10.21274/an.2017.3.2.295-320.

Suwikno, Dwi. 2010. Pengantar Akuntansi Syariah. Yogyakarta: Pustaka Pelajar. Tabe, Ridwan. 2013. "Sistem Informasi Akuntansi (SIA) Dalam Meningkatkan Kepercayaan dan Pelayanan Perbankan Syariah". Jurnal Ilmiah Al-Syir'ah 11 (1). http://dx.doi.org/10.30984/as.v11i1.164.

Triyuwono, Iwan. 2013. "So, What is Sharia Accounting?". Imanensi: Jurnal Ekonomi, Manajemen dan Akuntansi Islam 1 (1): 42-50. https://doi.org/10.34202/imanensi.1.1.2013.42-50.

Yeni dkk. 2016. "Faktor-Faktor Yang Mempengaruhi Kualitas Informasi Laporan Keuangan Pemerintah Daerah Kabupaten Teluk Wondama" Jurnal Emba 4 (3): 682-694. 